\title{
From Heaven Lake: A Thematic Analysis
}

\author{
Dr. Bipin Chandra Uniyal \\ Assistant Professor English \\ Bal Ganga Degree College \\ Tehr, Uttarakhand, India \\ bipinuniyal2511@gmail.com
}

Abstract

Culture is a running blood in the artery of a man or a country from which it makes all round progress. Nourished through culture, a citizen of a nation leaves a special identity before society and the other nations. Thus culture becomes synonym of a person, a society and a nation. If we neglect our culture, we cannot make all round progress because culture is a watchman a defender and a guard of our characters, morality and nationality. On the other side it describes the traditions of the past in the references of the present and the other it gives natural and calm acceptance to the new changes of society. It does not accept the negative aspects. Travel and culture are related to each other. Through travel one can get more particular view to a complete knowledge, which one had seen, better than any other information. If we are travelling through an area, we can survey and observe it in a better way. One comes very close to the people. So, 'Travel' is one best source of knowing culture. "Indica", written by a foreign traveller, Magsthenese, is the best source book on Indian culture and political system. Many foreign writers came in India and described Indian culture, society, economic pattern and condition and political system in their books. Among these writers are Huein-Tsang, Fi-hein, It-sing and Albaruni. Books written by these writers are best source of Indian culture.

Keywords: - Culture, Travel, Character, Morality, Population, Education, Politics, Economy, 
Revolution.

Vikram Seth is the most significant writer of Indian writing in English of modern age. Seth touches every aspect of literature. He wrote poems, stories and novels. Travel literature is a new trend in Indo Anglian literature introduced by Vikram Seth. He is considered as the pioneer of travel in Indo English literature. His book From Heaven Lake describes the journey through Sinkiang and Tibet. According to New Statesman, it is the perfect travel book. Seth got Thomas Cook Travel Book Award in 1993 for travel literature. The book is initially a travel literature, bringing to light a new and untrodden world of Tibet as well as Sinkiang. It is in itself a renaissance of travel, consisting of the fine Environmental landscapes and nature around. Through travel literature Seth depicts the realities of humanity.

Vikram Seth, born in the family of Mr. Prem Nath Seth and Mrs. Leela Seth in 1952, in Kolkata, is prolific writer and has written poems, stories, and novels. He is recipient of Sahitya Academy Award, Commonwealth Writers Prize, W. H. Smith Prize and many other awards and distinctions. So Vikram Seth's works are widely accepted both in India and abroad. Seth got world wide popularity because he presented before readers what they wanted. Seth's travel literature is full of realism, irony and humour. He has also shown human relationships. The incidents are portrayed in a vivid and realistic manner. Seth's depiction of reality is simple and impressive. From Heaven Lake is Seth's description of a personal experience into cultures of both the Chinese and the Tibetans. His experiences on Cultural Revolution of China form the basis of the culture he has brought to light in the book. Seth has affinity with both the Chinese and the Tibetan people, aspiring the betterment of relations with each of them.

Seth's From Heaven Lake is the outcome of his own experiences. His expression is vivid. In his novel, he aptly maintains the dignity of culture. The characters and incidents act and react in a natural way. Before Vikram Seth, in Indo-English literature, there is ample 
literature on political and social scene, but nobody wrote on travel. So the credit of travel writing goes to Vikram Seth, because he is the first writer, who introduced travel writing in Indo-English literature. From Heaven Lake is not only a travel description, but it also presents the real picture of political and social scene. Undoubtedly his travel literature is remarkable.

Culture is a running blood in the artery of a man or a country from which it makes all round progress. Nourished through culture, a citizen of a nation leaves a special identity before society and the other nations. Thus culture becomes synonym of a person, a society and a nation. If we neglect our culture, we cannot make all round progress because culture is a watchman a defender and a guard of our characters, morality and nationality. On the other side it describes the traditions of the past in the references of the present and the other it gives natural and calm acceptance to the new changes of society. It does not accept the negative aspects.

Travel and culture are related to each other. Through travel one can get more particular view to a complete knowledge, which one had seen, better than any other information. If we are travelling through an area, we can survey and observe it in a better way. One comes very close to the people. So, 'Travel' is one best source of knowing culture. "Indica', written by a foreign traveller, Magsthenese, is the best source book on Indian culture and political system. Many foreign writers came in India and described Indian culture, society, economic pattern and condition and political system in their books. Among these writers are Huein-Tsang, Fi-hein, It-sing and Albaruni. Books written by these writers are best source of Indian culture.

Vikram Seth did the same. He spent two years in China as a research scholar at Nanjing University. He did research on economic demography. He visited mostly the minority dominated areas. Seth has given a minute description of these minority areas of the 
economically backwards. Seth started his journey with a group of research scholars from Nanjing University. They first visited Turfan. Turfan lies in Xinjiang or Sinkiang, the northwest province of China, bordering on the Soviet Union. The meaning of Xinjiang is 'New Border Land'. The Chinese call it an autonomous region. This province is populated by minorities called non-Hans. Hans dominated the population of China. Tarin basin lies in the heart of Xinjiang desert. Uighures and Kasakhs live in the parts of former Soviet Union. These people of miniority regions have same religion. Vikram Seth narrates: 'they are Muslims in culture and religion; cultures based on the Orthodox Church or on Confucianism are equally alien to them. The script of the Uighur language is Arabic. The dress of the people on the streets outsides is colourful, unlike the drab ubiquitous blue of eastern China', (1). Hans people are more related to Turks than the Chinese. But China is the large populated nation. The larger part of China is covered with five or six percents of its minorities. "The government has attempted to ease the traditional strain by creating autonomous regions, counties and districts. The minority group have been encouraged to develop their own system of communication, style of life and educational and writing system', (2).

In Turfan, there are towers, domes, and places of old times. These were built in 1 B.C. At that time, in Turfan, there was Buddhist religion, but Muslims invaded it, and the people were converted into Muslims. Still there are Buddhist temples and monasteries in ruined conditions. The inhabitants, mostly the people of minor communities of China are very courteous, polite and interested in foreigners. They meet them very courageously and always feel glad. They talk with them very frankly. They develop tensionless friendship with the foreigners, enjoy their company and love the country from which the foreigners come. They are very amicable people. "Three naked children splash about in the stream and pause to greet us with bye-byes, of great vigour and friendliness. They have met foreigners before', (3). In the evening, often the troupes of musicians performs programme of songs and dances. 
Once Seth and his company participated and enjoyed it. They also sang the song in their term. Seth also sang a song from the film Awara (a film by Raj Kapoor).

After Turfan, Seth and his company arrive in Urumqui. This place is full of natural beauty. Anybody, who visits there could live for a long time. Little far away from Urumqui, there is a beautiful area, 'Tian Chi' or Heaven Lake. This is the area where one can live for a year, two year or many years. This region is full of piece, and is suitable for solitude and contemplation. Here is the Ming Tombs or the mausoleum of Sun Yat Sen. People often visits tombs. "Here, one can lie in the spring and autumn and also in summer. The roads, the observatory, the farms, with their overpowering odour of pig manure are a natural scene. There are the few places, where the poets, like Tao Yuanming or Wang Wei would feel at ease today"'(4).

Heaven Lake is long, saradine shaped and fed by snow melt from a stream at its head. The lake is an intense blue, surrounded on all sides by green mountain walls, dotted with distant sheep. " At the head of the lake is a massive snow capped peak, which dominate the vista, it is a part of a series of peaks that culminate, a little cut of view in Mount Bogda itself' (5). Seth swam at the Heaven Lake after the caution from Mr. Cao, owner of mount shop at the small cottage. There is a grand mosque in Xian. This mosque is constructed very well. There are inscriptions across in arch some in Chinese and some in Arabic. Seth tells: " This place is interesting half Arabic in style, half Chinese, you could find in any mosque in the world. But, this you would not see outside China. There is no God, but God, and Mohammed is his prophet', (5).

The religion of China is Buddhism. Budhhism came in China from India. In western China, the monastery at Dun-huang still preserves important wall painting based on sacred stories. Monumental sculpture, a contribution from northern India, gained popularity, and led to the creation of massive stone carvings of Buddhist deities in the mountain of 
Henan and Shanxi province. Wooden pagodas and architectural forms are a significant structural contribution of this period. By the 6th century, Buddhism had permeated nearly every facet of Chinese cultural life. At Dunhuang, there are caves in which the life of Buddha has finely been depicted. Here the image of Buddha is different from other countries. " In India Buddha has, I see by contrast a meditative calm, and in the great bronze Buddha of Kamakura in Japan, leaning slightly forward towards the people below, there is a look of compassion and tension so profound that its size is not longer overbearing"' (6)

Seth separated from his group and made a plan to visit Tibet from Liuyuan by truck. He got lift in a truck. Sui, thirty five years old truck driver and Xiao were very honest and responsible, has helped and taken care of Seth all through the journey and refused payments for many expenses. An incident happened as Seth's bag fell from the truck. This was containing the books, clothing and research materials. They informed to police and police caught the thief with the help of another truck driver. Everything was in the bag. It shows the duty and responsibility of a nation to give safety to the foreigners. To trouble and harm to the foreigner is not considered good. This is the nation's pride to give safety to foreigners.

China is rich in fruit production. They produce apricots, watermelon, grapes, gourds, and melon. These fruits are cheap in china, but the price of these fruits in Tibet is many times higher. Cultural Revolution in China played a great role in its development. Most of the people got frustration during the Cultural Revolution. Sui describes: " we never studied, never did anything. I was interested in books, but any reading I did, I did without guidance. My sister is a doctor, but that sort of things is completely closed off to me. I am too old now for higher studies. Besides, I don't have the qualifications"' (7). In such a way, the Cultural Revolution destroyed the future of many young children, those who wanted to get education.

Sui was compelled to be driver on truck. This was the tale of Sui and many others. They did not get higher education. Cultural Revolution was the main factor which completely 
changed the life of Chinese people. At this duration, China's cultural heritage - books, temples and works of arts were destroyed. Children were against to their parents and teachers. Sui again says: " some good things come out of it, as they do out of every disaster. I learned a lot of things about life, and about how people behave, about how far, for instance, you could count of even year best friends to stick by you in times of trouble. Sometime, people wanted to but they did not dare help. They feared for themselves and for their families"' (8). But now at the present, in China such kind of situation has been improved since Cultural Revolution. Education is widespread in China. A central concern of modern educated Chinese has been the question of whether or not any aspects of past tradition have a valid place in modern Chinese life. The conflict between nationalistic pride in China's great cultural heritage and the belief that all traces of the past must be eliminated in order to create a new China, presents an irresolvable dilemma for many.

Seth compares Indian political, economic and social system with that of China in view of what both countries did for their people in the duration of their independence. China has a better system of social distribution and social care. In India, things are mostly on the papers, while in China it is in practices. Both countries have a large population but the people of China are well clothed and well fed. They have achieved the better standards of living. In the reference of population growth, China has a better rate than India. They have strict rules pertaining to population growth. So in near future there is no fear to sink in poverty. While in India, there are not such types of strict rules about the population or birth control. This is noticeable that India is the first country to adopt the family planning programme.

Travelling strengthens human relationship. Qusha says to Seth: " I am glad things have improved in our relations" (9). Foreign relations get better by the public relations, more than the real politics, because the friendship of countries rests upon mutual understanding of people and their culture. To learn about another great culture is to enrich one's life to 
understand one's own country better, to feel more at home in the world and indirectly to add to that reservoir of individual good will that may be generated from now, temper the cynical use of national power. So such type of trends should be developed. People should be given permission to visit other countries. There should not have any restriction on the public interaction. 


\section{References}

Vikram Seth, From Heaven Lake: Travel through Sinkiang and Tibet, New Delhi: Penguin Books (India) Ltd. 1983, Page 03.

The Encyclopedia Americana, Danbury, Grolier Incorporated, 1829, Vol. XXVI, Page500

Vikram Seth, From Heaven Lake: Travel Through Sinkiang and Tibet, New Delhi: Penguin Books (India) Ltd. 1983, Page 07.

Ibid, page 19.

Ibid, page 31 .

Ibid, page 48 .

Ibid, page 74- 75 .

Ibid, page 76 .

Ibid, page 177.

Bibliography

Vikram Seth, From Heaven Lake: Travel through Sinkiang and Tibet, New Delhi: Penguin Books (India) Ltd. 1983, Page 03.

The Encyclopedia Americana, Danbury, Grolier Incorporated, 1829, Vol. XXVI, Page 500

Sherring, Charles A. ' Western Tibet and the Indian Borderland,' Delhi, Cosmo Publication, 1974.

Iyenger, K.R. Srinivas, 'Indian Writing in English', Bombay Asia Publishing House,1962

Parameshwaran, Uma, “'A Study of Representative Indo-English Novelists', New Delhi, Vikas Publishing House, 1975.

Mehta, P.P. ' Indo- Anglican Fiction: An Assessment', Bareilly, Prakash Book Depot, 1968.

Shashi, S. S. 'Encyclopedia of Humanities and Social Sciences', New Delhi, Anmol Publication, 1979. 